\title{
Jesus in the Bible and the Qur'an: a comparative study.
}

\author{
Ndongo Kamdem Alphonse \\ University of Uyo, Nigeria.
}

\begin{abstract}
Resume: Christians and Muslims both claim brotherhood with Jesus, son of Mary. Their respective arguments are based on the Bible and the Qur'an. Prophet Muhammad (SAW1), whom Muslims hold as the seal of the prophets, even goes further to say in one of his hadiths that no other person is closer to him, both in this world and in the world to come, than Jesus. The Holy Qur'an makes mention of his name more often than that of Muhammad (SAW) through whom it was revealed. A comparative study of this prominent religious figure would therefore be of great interest, using the Bible, the Quran and the Hadiths of prophet Muhammad (SAW) as primary sources.
\end{abstract}

\section{Introduction:}

No other religious figure has inspired more literature and raised more controversy than Jesus, son of Mary. Both Christians and Muslims claim brotherhood with him, and both religious communities are awaiting his second advent. Abu Ameenah Phillips (2001) supports that "Jesus Christ represents the common link between the two religions having the most followers on earth today, Christianity and Islam"(3) .Many nonMuslims are ignorant of the fact that the Qur'an speaks at length, and in glorious terms, about Jesus, even about things which are not mentioned in the Bible. Moreover, prophet Muhammad (SAW) says in many of his Hadiths that he is the nearest of all the people to Jesus, both in this world and in the world to come, and that Jesus will come towards the end of the world, as also believe Christians. A comparative study of Jesus' status from the Christian and Muslim perspectives would therefore reveal what the Bible says about him (here, we will distinguish between what Jesus says about himself and what others say about him), what the Qur'an says about him (Allah alone speaks in the Qur'an; any other voice is quoted by Him) and what prophet Muhammad (SAW) says about him in his hadiths. Our work will be based on three main sources: the Bible, the Qur'an and the Hadiths of prophet Muhammad (SAW).

\section{Reading from the Bible:}

Jesus' saga starts in the Bible with his birth, which is recorded in two gospels only. In Matthew 1: 18-25) and Luke (1: 31-35), it is recorded that angel Gabriel was sent by God to the virgin Mary, to inform her of the favour bestowed upon her to be the mother of a miraculous son, whose name shall be Jesus. However, while Matthew 2:2 (see also Mark 15:2) calls this child 'King of the Jews', Luke 2:11-12 goes further to call him 'a saviour, who is Christ the Lord (see also John 4:42).

Jesus, the Christ, is born of a woman, but without the intervention of a man, which makes his birth to be considered miraculous: he is the word of God made flesh; 'Be! and it is'. Consequently, his father can only be God, the author of life. Matthew 3:17 quotes God as having said, referring to Jesus, "This is my beloved son in whom I am well pleased" (see also Matthew 17:5), to the hearing of the crowd gathered at the Jordan sea to be baptized by John the Baptist, even though Jesus himself warns his followers that the Father who sent him has born witness to him: "His voice you have never heard, his form you have never seen..."(John 5:37), thus distinguishing himself totally from God. We are now left to ask whose voice is recorded in Matthew 3:17. But that is another topic.

In Matthew 8:28, two demoniacs call Jesus 'son of God'. It may be interesting to point out here that not even once does Jesus call himself 'son of God' in the Bible, except in Matthew 27:43 where he is reported as having said "I am the son of God". But, this is a quotation from those who want to crucify him. Could he have decided to keep silent from mankind such a crucial information? Being, not the son of man, but the son of God? And for what reason would he have hidden such information?

In the contrary, each time Jesus refers to himself, he calls himself 'son of man', and this appears about eighty times in the Bible. About the nature of God, Numbers 23:19 has this to say:

God is not a man, that He should lie,

nor a son of man, that He should repent.

Lies and repentance are human attributes. Whatever the case, Jesus states in Matthew 20:23 that he is powerless without God, when a woman comes to him and pleads for her two children: 
Command that these two sons of mine may sit, one at your right hand and one at your left hand in your kingdom.

Jesus answers her, saying:

...to sit at my right hand and at my left is not mine to grant, but it is for those for whom it has been prepared by my Father.

The same statement is recorded in Mark 10:40, relating the same incident. In John 5:19, talking about himself, Jesus tells the Jews who came to persecute him that "The son can do nothing on his own accord, but only what he sees the Father doing; for whatever he does, that the son does likewise". In the same gospel (John 5) verse 30, he adds:

I can do nothing on my own authority; as I hear, I judge; and my judgement is just, because I seek not my own will, but the will of him who sent me.

In other words, Jesus claims to be subordinate to God who sent him. He is just the messenger of God, which is not given to everyone, but only to the few privileged, the Christs. In John 6:38, Jesus emphasises that he has not come down from heaven to do his own will, but the will of him who sent him. In John 7:28, while teaching in the temple, Jesus tells the crowd listening to him that he has not come (on earth) on his own accord, that he who sent him is true, that he knows him (God) because he it is that sent him. In John 8:28, he yet has this to add:

When you have lifted up the son of man, then you will know that I am he, and that I do nothing on my own authority but speak thus as the Father taught me. And he who sent me is with me; he has not left me alone, for I always do what is pleasing to him.

In John 14: 28-29, Jesus clears any doubt about his status and his relationship with God. Talking to his disciples, he tells them that he is going away, but that he will come back to them. Surprised of their reaction to this information, he insists:

You heard me say to you, "I am going away, and will come back to you". If you loved me, you would have rejoiced, because I go to the Father; for the Father is greater than I.

What actually is Jesus' assignment on earth? The first instance where Jesus identifies himself as a prophet occurs in Matthew 5:11-12, when he warns his disciples about the persecution they will face because of him, "for so men persecuted the prophets before you". In Matthew 10:40-41, he also identifies himself as a messenger and prophet when he tells his disciples, who are about to go out to preach his gospel, that he who receives them receives him, and he who receives him receives the person (God) who sent him. In Matthew $21: 11$, it is reported that the crowd, on hearing Jesus speak, say:

This is the prophet Jesus from Nazareth of Galilee.

When the chief priest and the Pharisees listened to Jesus, they were not happy with the parable he was using, for they knew he was speaking about them. When they tried to arrest him, "they feared the multitudes, because they held him to be a prophet" (Matthew 21:46).

In Luke 7:16, Jesus gives back life to a dead man, just by commanding the body to rise. Fear seized the crowd witnessing this miracle, "and they glorified God, saying, "A great prophet has risen among us!" Likewise, in Luke 13:33, Jesus tells the crowd that he has to go back to Jerusalem, "for it cannot be that a prophet should perish away from Jerusalem". Of course, "Jesus is a prophet mighty in deed and word before God" (Luke24:19). However, upon all these evidences about Jesus' prophethood and his subordination to Almighty God, Paul contends in Acts 3:15 that Jesus is the author of life, though he was killed, according to the Bible, by a human being. Paul says:

The God of Abraham and of Isaac and of Jacob, the God 
of our fathers, glorified his servant Jesus, whom you delivered up and denied in the presence of Pilate when he had decided to release him. But you denied the holy and righteous one, and asked for a murderer to be granted to you, and killed the Author of life, whom God raised from the dead. To this we are witnesses.

In this extract, Paul equates Jesus to god by calling him the author of life. Some churches today call Jesus God himself, while others say he is one of the Three. In any case, Jesus refers to himself as a messenger, a servant and a prophet of God, sent on earth by Him through the womb of a woman for a temporal assignment. What does the Quran say about him?

\section{Reading from the Quran:}

The Quran is held by Muslims as the last message or testament sent to mankind by Allah, which implies that other messages or testaments were sent before it (see Surah 2:136). We would also want to remind here that this last message was revealed to prophet Muhammad (SAW) by angel Gabriel. It may be interesting to observe that Jesus' name is mentioned in the Quran more often than that of prophet Muhammad; that there is no reference to prophet Muhammad's mother in the Quran, while there is a full chapter or Surah on Maryam, the mother of Jesus (Surah to Maryam, or Surah $19^{\text {th }}$ ). Can a human being be more honest?

Jesus' story starts in the Quran with the announcement of his birth to the virgin Mary by angel Gabriel. "How can I have a son when no man has touched me, nor am I unchaste", she replied (Surah 19:20). Angel Gabriel answers her thus:

...So will it be, your Lord said: 'That is easy for me. And we wish to appoint him as a sign for mankind and a mercy from Us, and it is a matter already decreed.

Thus, the miraculous birth of Jesus poses no doubt: he is the word of God made flesh. "...Allah creates what he wills. When He has decreed something, He says to it only: 'Be!'- and it is" (Surah 3:47). His mission on earth is clearly stated in Surah 3, verse 49: he will be a messenger to the children of Israel, and he will confirm what is in the Thora that was revealed before him.

According to the Bible, Jesus performed his first miracle during a feast when there was shortage of wine. He asked his disciples to fill drums with water which he transformed into wine. He was about thirty three years old. The Quran does not mention this incident. However, Jesus' first miracle is recorded in the Quran when he was less than a day old (less than twenty four hours), just some few hours after his birth. His mother was instructed by angel Gabriel to keep quiet when her people question her about the child (Jesus), for, the angel was aware that she would be accused of being unchaste. So after giving birth, she wrapped the child and came to her people. The Quran reads thus, in Surah 19:

...They said: 'O sister of Harun! Your father was not a man who used to commit adultery, nor your mother an unchaste woman (verse 28). Then she pointed at him (the baby). They say: 'How can we talk to one who is a child in the cradle?' (verse 29). He (IsaJesus) said: 'Verily I am a slave of Allah, He has given me the

Scripture and made me a prophet (verse 30). And He has

made me blessed wheresoever I be, and has enjoined on me salat (tide) as long as I live (verse 31)

Jesus in this quotation is just a new born baby, and this revelation was sent down to mankind through prophet Muhammad, who never met Jesus, who was not from Jesus' lineage or family, but who just believed him because the revelation came from God Almighty. In essence, prophet Muhammad believed and enjoined on Muslims to believe that Jesus performed such a miracle when he was less than twenty four hours old, just because Allah said so through angel Gabriel. Any Muslim who nurtures even an atom of doubt about such a truth casts himself automatically out of Islam.

Jesus says in John 5:30 that he can on his own do nothing, but that he speaks and acts according to his father's instructions. As a follow up to this, the Quran says that he will speak to people in the cradle (3:46); that Allah will teach him the Scripture, knowledge, the Thora and the Gospel (3:48); that he will be a messenger to his people (Israel), confirming what was sent before him (3:50), as supported by Matthew 5:17. Among his early miracles was, when still a child, the power bestowed on him by Allah to design out of clay a figure like that of a 
bird, to breathe into it and it becomes a living bird by Allah's permission. This other truth was also revealed to prophet Muhammad, the Bible does not account for it, and no Muslim can have any doubt about it.

The Quran enjoins on Muslims to believe in Allah, in the Quran, in Abraham and the message he was sent with; in Ismael and Isaac, Jacob and his offspring; in Moses and his message; in Jesus and his message, and in all that was given to prophets from their Lord (2:136). Most importantly, it is counted as sin in Islam to make any distinction among prophets as to who is more or less important, for they all come from the same Lord at an appointed time in human history. Ulfat Aziz-Us-Samad (2001) supports that "un musulman doit croire dans les fondateurs de toutes les grandes religions" (5) [A Muslim must believe in the founders of all great religions].

Thus, Jesus is portrayed as a prophet and a messenger of Allah sent on earth for a particular assignment, at a particular time, to a particular community and with a particular message. In Surah 4:71, Allah calls upon the people of the book (Christians) not to exaggerate in their religion by saying "Three" (i.e. Trinity); that Allah is unique and that "The Messiah Isa (Jesus), son of Maryam, was no more than a messenger of Allah, and His word which He bestowed on Maryam, and a Spirit created by Him". Moreover, Surah 5:46, 75, 78, 112, 114; Surah $33: 7 ; 42: 13 ; 57: 27$ and 61:6 confirm Jesus' status as a messenger and prophet of Allah. But what is the relationship between Jesus and Allah in terms of sonship, in the Quran?

Allah says in Surah 2:116 that He does not need a child for himself, because $\mathrm{He}$ is the owner of mankind and everything visible and invisible. "Verily, the likeness of Isa (Jesus) before Allah is the likeness of Adam. He created him from dust, then said to him: 'Be!'- and he was"(Surah 3:59). As such, Jesus has no share in divinity, which is the sole prerogative of Allah: He has neither a wife nor a son (Surah 3:62-62). In Surah 9:30, Allah goes further to curse those who attribute a son to Him, and those who take their rabbis and their monks as their lords besides Him. Surah 19:89 qualifies as "a terrible evil thing" the believe that Allah has begotten a son. According to Aisha Lemu (2001), "To attribute a child to God would be to deny God's perfection. It implies that He lacked or needed something" (3). Surah 23:91 reads thus:

No son did Allah beget, nor is there any ilah (god) along with

Him...Glorified is Allah above all that they attribute to Him.

Thus, from the Islamic perspective, Jesus has no link to divinity. He is a messenger like others who came before him and like the one (Muhammad) who came after him. Allah calls unbelievers those who contend that the Messiah (Jesus), son of Mary, is God (Surah 5:17) while he (Jesus) has enjoined on his people to worship Allah, his lord and their lord (Surah 5:72-73). In the verses 116 and 117 of the same Surah (5), Allah reminds mankind of the day He will question Jesus about the attributes of divinity which his mother and him were given by their people. Here is Jesus' answer:

Glory be to You (verse 116)...Never did I say to them aught except what You did command me to say: 'Worship Allah, my lord and your Lord' (verse 117).

In Surah 6:85, Jesus is held to be a righteous servant of Allah, along with Zaccharia, John, Elijah. While announcing the advent of Jesus, angel Gabriel calls him "a righteous son" (Surah 19:19). He is "a sign to mankind and a mercy" from Allah (Surah 19:21), for he brings glad tidings to his people. Many non Muslims may be surprised to learn that prophet Muhammad announces the second coming of Jesus as one of the major signs of the end of time. The Quran states:

And he (Isa-Jesus) son of Mary, shall be a known sign for the Hour...

$(43: 61)$

This quranic truth is even more explained in some of the hadiths of prophet Muhammad (SAW) which we want to explore in the following lines.

\section{Reading from the hadiths of prophet Muhammad:}

Islam as religion has two majors sources or texts: the first and the most important one is the Quran, the primary source held as the pure words of Allah. Him alone speaks in the Quran, and any other utterance which is not His is quoted by Him. The second source is the hadiths of prophet Muhammad (SAW), which is an account of what he said or did, what he approved or condemned. Many of such hadiths refer to Jesus.

In one of them, prophet Muhammad (SAW) said that if one testifies that there is no god to be worship but Allah alone, who has no partner, and that Muhammad is His slave and His apostle, and that Jesus (Isa) is Allah's slave and apostle, and His word which He bestowed on Mary, and a spirit created by Him, and that 
Paradise is true, and Hell is true, Allah will admit him into Paradise with the deeds which he had done, even if those deeds are few (Al-Bukhari 1431).

In yet another hadith, prophet Muhammad (SAW) contends that he is the nearest of all the people to Jesus, son of Mary, that there has been no prophet between Jesus and him, that all prophets are paternal brothers, that their mothers are different but their religion is one (Al-Bukhari 1436 and 1437). He also warned his followers not to exaggerate in praising him as the Christians praised the son of Mary, for he was only a slave of Allah (AlBukhari 1439). Then he announced the second coming of Jesus as one of the major signs of the end time, and he foretold that he, Jesus, will descend among mankind and live by what he, Muhammad (SAW), left behind (i.e. the Quran and his Sunnah- Al-Bukhari 1440).

Among the assignments Jesus will do in his second coming, prophet Muhammad told us, is the establishment of the true religion and the killing of the Anti-Christ, the false Messiah. "By Allah, he said, the son of Mary will shortly descend among you, and will judge mankind justly" (Al-Bukhari 2059). By that time, the Anti-Christ would have caused havoc on earth:

While he will be doing so, Allah will send prophet Iesa (Jesus), the son of Maryam. He will descend at the white Minaret in the East of Damascus... Iesa will look for the Dajjal. He will find him at Ludd...(Al-Bukhari 2048). When the enemy of Allah (the Anti-Christ) will see him, he will dissolve like salt dissolves in water. Were Iesa to keep looking at him, he would have vanished, but Iesa will kill him by the power of Allah...(Al-Bukhari 2029).

\section{Conclusion:}

In his book entitled $A$ Western Awakening to Islam, Lord Headley contends that «L'Islam et le Christianisme, comme enseigné par le Christ lui-même, sont des religions soeurs, séparées l'une de l'autre à cause des dogmes et des considerations d'ordre technique dont on pourrait bien se passer » (15) [ Islam and Christianity, as taught by the Christ himself, are sister religions, separated one from the other by dogmas technical considerations, which could be done away with].

From the Bible, we gather what Jesus says about himself, what people say he said about himself, and finally what people say about him. If these three levels of information do not concord, then the most reliable truth is what comes from Jesus himself. He refers to himself as "son of man", servant, messenger and a prophet of God. The Bible tells us that God is not a man, as we have seen in Numbers (23:19). The third person goes ahead and calls him "son of God", "saviour" and "author of life", thus giving him the attributes of God. If Jesus has said the truth, namely, that no one has ever heard the voice of God, then the voice that claims Jesus to be his "beloved son" is not that of God. "The absence of the original manuscript of the Bible has given way to all these discrepancy from translators" (Ulfat Aziz-Us-Samad 2001: ). About the deviation from the original manuscripts of messages sent to mankind by God, Simon Alfredo (2008) has this to say:

The level of deviation and uncertainty depends on the degree of precision with which every word revealed to the prophets was transmitted to others. If these words have not been accurately transmitted and have instead suffered adulteration, it is highly likely that the essence of the original message would be lost forever.

Consequently, in order to make a just and unbiased comparison

between Christianity and Islam, it is necessary to determine the extent to which the original Gospel and the Qur'an have been kept free from adulteration, additions or deletion" (10).

In any case, the Quran concords with Jesus' utterances about himself: he is the son of man, created, though miraculously, but like Adam. Jesus had the privilege of sojourning nine months in the womb of his mother, who gave birth to him through the normal process, cleaned him, suckled him and saw him grow up. Adam did not have that privilege. After moulding him from clay, Allah just told him "Be!", and he was. But nobody has ever thought of calling Adam son of Allah. Today, Jesus has been graduated from the status of son of god to that of God himself. However, it is interesting to notice that Jesus has never arrogated himself such a status. All prophets, from Noah to Muhammad, laid emphasis on the uniqueness of God. Surah 112 of the Holy Quran reads thus:

Say: He is Allah, the One

Allah us-samad (Allah the self-sufficient Master) 
He begets not, nor was He begotten.

And there is none co-equal or comparable to Him.

Note:

1- En Arabe: Salallahu alay wa salam: que la paix et la bénédiction d'Alla soient sur lui. Prière que doit prononcer tout Musulman lorsque le nom du prophète est mentionné.

\section{Works consulted:}

[1]. Alfredo Carabello, Simon. My greatest love for Jesus led me to Islam. Jeddah: Daroussalm, 2008.

[2]. Aziz-Us-Samad, Ulfat. L'Islam et le Christianisme. Riyadh : Internationl Islamic Pub. House, 2001.

[3]. Baagil, H.M. Muslim-Christian dialogue. Jeddah : Islamic Educ. Foundation, 1984.

[4]. The Holy Bible. Revised Standard Version.

[5]. Bilal Phillips, Abu Ameenah. The true message of Jesus Christ. Hamzat intl.

[6]. Ibrahim, I.A. et al. A brief illustrated guide to understanding Islam. Houston:

[7]. Lemu, Aisha B. Let us reason together. Minna: Islamic Educ. Trust, 2001.

[8]. Bucaille, Maurice. La Bible, le Coran et la Science. Paris : Seghers, 1976.

[9]. Miller, Garrry. The amazing Qur'an. Jeddah : Abul-Qasim Pub. House, 1994.

[10]. Le Chistianisme : origine et réalité. Ouvrage collectif dirigé par Moujahid,

Lagos: Hamzat Intl Pub House, 1996.

Daroussam, 1997.

[11]. Nakata, Khaula. View through Hijjab. Jeddah: Abul-Qasim Pub. Hous, 1994.

[12]. The Holy Qur'an. English translation by Dr. Muhammad Taqi-ud-Din A, and Dr. Muhammad Muhsin K

[13]. Al'Bukhari concise volume. English transl. by Mohammad Mahdi AlSharif. Beirut: Dar-al Kotob al Ilmiyah, 2006.

[14]. Sahih Muslim. Compiled by Al-Hafiz Abdul-Azim Al-Mudhiri. Riyad: Daroussalam, 2003. 